\title{
Age Less than 80 Years
}

National Cancer Institute

\section{Source}

National Cancer Institute. Age Less than 80 Years. NCI Thesaurus. Code C138938.

An indication that an individual's age is or less than 80 years. 